\title{
Experience with microbiological assay for folate using a chloramphenicol-resistant $L$. casei strain
}

\author{
I. CHANARIN, RITA KYLE, AND JENNIFER STACEY
}

From the Department of Haematology, Northwick Park Hospital and Clinical Research Centre, Watford Road, Harrow, Middlesex

SYNOPSIS Experience with a semi-automated $L$. casei folate assay using a chloramphenicol-resistant strain of organism is described. Control of $p \mathrm{H}$ of medium and incubation time was required. The $\mathrm{N}$ normal range for serum folate was 2 to $16 \mathrm{ng} / \mathrm{ml}$ and red cell folate 200 to $600 \mathrm{ng} / \mathrm{ml}$.

Microbiological assay of folate in serum and red cells has been simplified by the use of a chloramphenicolresistant strain of the assay organism, Lactobacillus case $i$, and by combining the use of this organism with an automated setting up and reading system. By including chloramphenicol in the assay medium the need for sterile precautions is obviated and it becomes possible to set up the assay by the single step of adding serum or haemolysate directly to an inoculated single-strength medium. A relatively expensive system for carrying out this dilution and subsequently for the reading of the assay is available (Davis, Nicol, and Kelly, 1970; Millbank, Davis, Rawlins, and Waters, 1970; Colvin, Gibson, and Neill, 1971). Although studies on the cost effectiveness of this system have not been published it could justify its cost in laboratories performing hundreds of assays each week. A busy laboratory, even serving a number of hospitals, will usually assay 50 to 100 specimens a week. Under these circumstances, the advantages of this system in rapid setting up of the assay can be achieved with a relatively inexpensive autodiluter, the results being read in the usual way. Although there have been few publications on this topic a number of laboratories have adopted this simpler alternative. The purpose of this report is to describe experiences with this method.

\section{Materials and Methods}

The technique for the conventional microbiological assay using $L$. case $i$ has been set out by Chanarin (1969). The following modifications are made using a chloramphenicol-resistant strain.

CHLORAMPHENICOL SOLUTION

Chloramphenicol base BP, $0 \cdot 1 \mathrm{~g}$, is added to $100 \mathrm{ml}$

Received for publication 24 October 1971.
$1 \%$ ethanol. This is stable for at least four weeks at $\mathrm{O}$ $4^{\circ} \mathrm{C}$ and is used to add to the assay medium.

MAINTENANCE OF ORGANISM

The chloramphenicol-resistant strain of $L$. case is obtained from Torrey Research Station, Aberdeen. ํㅡㄴ Chloramphenicol sodium succinate is dissolved in $\overrightarrow{0}$ broth to give concentrations of $300 \mu \mathrm{g}$ and $100 \mu \mathrm{N}$ chloramphenicol per $\mathrm{ml}$. The broths are distributed in $10 \mathrm{ml}$ volumes and sterilized by heat at $10 \mathrm{~m}$ pressure for 10 minutes. The stock culture is kept in the broth containing $300 \mu \mathrm{g}$ chloramphenicol per $\mathrm{ml}$ at $4^{\circ} \mathrm{C}$. It is subcultured weekly.

For assay, $L$. casei is subcultured into broth containing $100 \mu \mathrm{g}$ chloramphenicol per ml incubated $\overrightarrow{\vec{O}}$ for 24 hours at $37^{\circ} \mathrm{C}$, subcultured again next morn- 3 ing, and again eight hours later. The latter culture is incubated overnight, a subculture made for main-? tenance into $300 \mu \mathrm{g}$ chloramphenicol broth, and the rest used to seed the assay medium as described: below.

PREPARATI ON OF ASSAY MEDI UM

Single-strength medium is made up, allowed to coolo to room temperature and $10 \mathrm{ml}$ chloramphenicol $>$ solution and $1 \mathrm{~g}$ ascorbic acid added for each을. $1000 \mathrm{ml}$ of single strength medium. The $p H$ is adjusted to $6 \cdot 1-6 \cdot 3$ using $3 \mathrm{~N}-\mathrm{KOH}$ solution and any precipitate allowed to settle and clear medium decanted. Five $\mathrm{ml}$ medium is set aside to serve for zero setting of the colorimeter.

The $L$. casei culture is 'washed' in three $10-\mathrm{m}$ aliquots of assay medium and resuspended in $2 \mathrm{~m} \frac{\mathrm{D}}{\mathrm{D}}$ assay medium. From $0 \cdot 1-0.15 \mathrm{ml}$ of inoculum iș̣ added to each $1000 \mathrm{ml}$ of assay medium. The organism is kept in suspension during manipu lations with a magnetic stirrer, an asbestos sheef 
being placed between the flask and stirrer to avoid warming the medium.

PREPARATION OF STANDARD CURVE

The stock solution of carefully dried pteroylglutamic acid is made by dissolving $150 \mathrm{mg}$ in $1000 \mathrm{ml}$ of $25 \%$ ethanol with alkali to bring folate into solution. A working solution of $150 \mathrm{ng} / \mathrm{ml}$ is made by preparing a 1 in 1000 dilution of the stock solution. Further dilutions are set up using the range suggested by Davis et al (1970), initial dilutions being made in $100 \mathrm{ml}$ volumetric flasks as follows (Table I).

\begin{tabular}{lrrrrrrrrr}
\hline & 0 & 1 & 2 & 3 & 4 & 5 & 6 & 7 & 8 \\
\hline $\begin{array}{l}\text { Folic acid } \\
\text { (150 ng/ml) }\end{array}$ & 0 & 1 & 2 & 3 & 4 & 6 & 8 & 10 & 12 \\
$\begin{array}{l}\text { Distilled water } \\
\text { (ml) }\end{array}$ & 100 & 99 & 98 & 97 & 96 & 94 & 92 & 90 & 88 \\
$\begin{array}{l}\text { Folateconcentration } \\
\text { (ng/ml) }\end{array}$ & 0 & 1.5 & 3.0 & 4.5 & 6.0 & 9.0 & 12.0 & 15.0 & 18.0 \\
\hline
\end{tabular}

Table I Standard curve

\section{PREPARATION OF SAM PLES}

Sera stored with ascorbate are assayed without any further preparation. Red cell folate is assayed by making an initial 1 in 20 dilution of whole blood into $1 \%$ ascorbic acid solution in distilled water. The PCV of the blood sample must be noted.

\section{AUTODILUTER}

Our experience has been with a Fisons automatic diluter calibrated to take up an $0.05 \mathrm{ml}$ volume and dilute it with $4.95 \mathrm{ml}$ assay medium. The components of the syringe are kept 'clean' by boiling in distilled water and the rest of the equipment is cleaned by running through not less than 1 litre of distilled water before and after each assay.

\section{THE ASSAY}

Using the autodiluter $50 \mathrm{ml}$ of inoculated cool single strength medium is run through. All specimens are set up in triplicate, $0.05 \mathrm{ml}$ of each specimen being taken up and ejected into the assay tube with 4.95 $\mathrm{ml}$ of inoculated medium. Flasks containing standard solutions, sera, and haemolysates are treated in the same way.

The tubes are covered with a metal tray and incubated at $37^{\circ} \mathrm{C}$ for 22 hours. Five ml water is added to all tubes before reading. The tube containing uninoculated medium alone is incubated and diluted in the same way and used to zero the colorimeter.

\section{CALCULATION}

Serum folate values are read directly from the standard curve. The reading for red cell folate is adjusted as follows:

$\left(\right.$ Reading $\left.(\mathrm{ng}) \times 20 \times \frac{100}{\mathrm{PCV}}\right) \mathrm{ng}$ folate $\mathrm{ml} \mathrm{RBC}$

\section{Results}

Two factors appeared to have a marginal effect on the assay results, viz, initial $p \mathbf{H}$ of the assay medium and the duration of incubation.

The recovery of a known amount of pteroylglutamic acid added to serum was most satisfactory when the $p H$ of the assay medium was between $6 \cdot 1$ and 6.3. The results were less affected when pteroylglutamic acid was added to whole blood haemolysate (Table II). Recovery of pteroylglutamic acid was complete after 22 hours of incubation and was generally reduced with a shorter incubation time (Table III). The addition of folate-free serum to the standard curve did not have any appreciable effect on the result.

\begin{tabular}{llc}
\hline $\begin{array}{l}\mathrm{pH} \text { of } \\
\text { Assay } \\
\text { Medium }\end{array}$ & \multicolumn{2}{c}{ Mean Recovery of PteGlu $(6 \mathrm{ng})$ Added to } \\
\cline { 2 - 3 } & Serum (\%) & Haemolysate (\%) \\
\hline 5.5 & 110 & 113 \\
5.8 & 106 & 112 \\
6.1 & 96 & 98 \\
6.2 & 94 & 93 \\
6.3 & 99 & 97 \\
6.4 & 95 & 91 \\
6.5 & 86 & 91 \\
6.7 & 82 & 97 \\
6.9 & 73 & 102 \\
\hline
\end{tabular}

Table II Recovery of pteroylglutamic acid at different initial $\mathrm{pH}$ of the assay medium (mean of three assays)

\begin{tabular}{lll}
\hline $\begin{array}{lll}\text { Incubation } \\
\text { Time } \\
(\mathrm{hr})\end{array}$ & \multicolumn{2}{c}{ Mean Recovery of PteGlu $(6 \mathrm{ng})$ Added to } \\
\cline { 2 - 3 } & Serum (\%) & Haemolysate (\%) \\
\hline 18 & 83 & 90 \\
19 & 90 & 93 \\
20 & 90 & 93 \\
22 & 99 & 99 \\
\hline
\end{tabular}

Table III Recovery of pteroylglutamic acid at varying incubation times (mean of three assays)

Blood samples from 69 members of the hospital staff were obtained during the course of a blood donor session. These were assayed for serum and red cell folate content by the conventional $L$. case $i$ assay using deproteinized serum and haemolysate specimens and with the chloramphenicol-resistant strain using whole serum and haemolysate. Results are shown in Table IV. The data show a skew distribution and $\log$ values were used in determining means and standard deviation. 
Serum folate was lower using the chloramphenicolresistant $L$. casei than with the conventional method. Red cell folate values were higher with the chloramphenicol-resistant strain than with the conventional one.

The blood donor specimens were assayed separately on two occasions and the results are given separately in Table IV (1) and (2).

Fourteen patients with megaloblastic anaemia due to folate deficiency had red cell folate values between 40 and $190 \mathrm{ng} / \mathrm{ml}$.

\section{Discussion}

The technique of folate assay using whole serum or haemolysate and a chloramphenicol-resistant organism is easier and quicker to set up than the conventional method. Unlike others, we have not been successful, despite considerable effort, in getting more or less identical results by the two methods. Perhaps in this respect our results mirror what most laboratories can expect in a change over to this technique. On the other hand the conventional folate assay in our hands at St Mary's Hospital, ì Paddington, regularly gave red cell folate results from 100 to 450 with a mean of 240 . Apparently the $\vec{N}$ same technique in a new hospital (Northwick Park) $\vec{\circ}$ now gives us significantly higher values for red cell ${ }^{\circ}$ folate, viz, 200-600 normal. This, too, we are unable 음 to explain but this is not surprising in view of the fairly wide variation in normal ranges recorded by different workers using essentially similar techniques (Chanarin, 1969).

Correct $p \mathrm{H}$ and control of incubation time were $\underset{\Phi}{\widetilde{\Phi}}$ necessary for full recovery of added pteroylglutamic acid in the assay.

\section{References}

Chanarin, I. (1969). The Megaloblastic Anaemias, pp. 308-319. Blackwell, Oxford.

Colvin, G., Gibson, G. L., and Neill, D. W. (1971). Use of the 'Analmatic clinical system' in the microbiological assay of $\stackrel{\mathbb{Q}}{\varrho}$ vitamin $B_{12}$ and folic acid in serum. J. clin. Path., 24, 18-22.

Davis, R. E., Nicol, D. J., and Kelly, A. (1970). An automated method $\overrightarrow{\vec{B}}$ for the measurement of folate activity. J. clin. Path., 23, 47-53.

Millbank, L., Davis, R. E., Rawlins, M., and Waters, A. H. (1970) Automation of the assay of folate in serum and whole blood. J. clin. Path., 23, 54-59. 